\section{Human Dignity and Its Premises in the Pandemic Crisis}

\section{Gabriela NEMT,OI 1}

${ }^{1}$ Associate Prof. PhD, "Ştefan cel Mare" University of Suceava. gabriela.nemtoi@,fdsa.usv.ro

\begin{abstract}
Human dignity is a component that is part of the quality of existing as a human being even if the latter is the product of creationism or evolutionism. In its content, dignity is the carrier of complex scientific valences, combining the philosophical-religious paradigm with the legal one. In this context, the literature presents human dignity as an aspect traditionally associated with the division of public law, which evokes a super-positive reality, synthesizing elements of religion, ethics and morals located in a position superior to positive law, orienting the latter.

The modern meaning given to human dignity oscillates between the illustrative character and the prescriptive character being constituted, in a complex sense, by the fusion between the moral content and the coercive right (Habermas, 2010, pp. 464-480) and, from another perspective, a stable notion that presupposes an objective moral principle that makes possible the legal recognition of human rights. The inability to include human dignity as a right in a unitary conceptualization leads, first of all, to the vast philosophical hermeneutics that is implicit in the discourse on dignity.
\end{abstract}

Keywords: Rights and freedoms, the right to life, human dignity, crisis situation.

How to cite: Nemțoi, G. (2021). Human Dignity and Its Premises in the Pandemic Crisis. European Journal of Law and Public Administration, 8(2), 01-14. https://doi.org/10.18662/elipa/8.2/155 


\section{Introduction}

The syntagma buman dignity is built on several concepts, namely, a first opinion refers to a concrete notion that implies a moral principle the essence of which makes possible the legal recognition of human rights. (Schultziner, 2007, p. 73-92). Thus, this concept functions as a form of utilitarianism of the rules according to which individuals must conform to human dignity because it is the only principle according to which it is possible to maximize human well-being, in the sense established by the categorical imperative of Kantian origin which attests to the treatment of each individual in itself, and a second opinion outlines the difficulty of conceptualizing human dignity which is argued by the flexibility of the legal qualifications that define it.

In legal terms, human dignity simultaneously fulfils the quality of: (1) supreme normative value - being identified as a foundation and positivist legitimation of all human prerogatives; (2) legal principle - representing a fundamental idea that shapes, the legal norm through which a certain individual prerogative is enshrined; (3) human right - this legal consecration of dignity is enshrined through the fundamental laws of the states of the world.

Human dignity through the construction of legislation becomes a priority in the relationship between state and citizen. Thus, in Chapter I, with the marginal name Fundamental Rights, the Constitution of the Federal Republic of Germany states that: Human dignity is inviolable. Its observance and protection are in the attention of the state. Similarly, Article 10 of the Constitution of South Africa regulates the right of every individual to respect for and protection of human dignity. Constitutional jurisprudence demonstrates that the field of human dignity is convergent and evolves towards identifying the legal meaning of human dignity in a negative way; consequently, treating the individual in a way that creates deficiencies in the exercise of the right to dignity is equivalent to reifying him.

In this regard we mention the case of Prinsloo vs. Van der Linde (Constitutional Court Of South Africa, 1997), in which the Constitutional Court of South Africa responds by a judgment recognizing the dignity of persons of color (Constitutional Court Of South Africa, 1997). 
In practice of the German Constitutional Court raises the issue of dignity through a case that calls into question the sentencing of an individual to life imprisonment, without the vocation to benefit from bail. Regarding this punitive possibility, the Constitutional Court of the Federal Republic of Germany held that: the state must consider every individual in society as having equal value (Köhne, 2003, p. 227).

In Romania, the Fundamental Law establishes at a high level a special attention on human dignity in the context of the constitutionalization of freedoms. By jurisprudence, the Romanian Constitutional Court has assigned a hybrid legal nature to the concept of human dignity, this being decomposed according to the following meanings: (Constitutional Court, 2019, paragraphs 47-53).

The Charter of Fundamental Rights of the European Union (European Union, 2012) individualises human dignity both structurally (organized in 7 Titles, the Charter begins with the Title entitled "Dignity") and substantially.

Assimilated in the structure of the individual, dignity cannot be justified as a right of a singular nature, it is conceived around the natural person consecrated with other elements such as private life, social life, public order, inviolability, etc. The syntagma human dignity is built on several concepts, namely, a first opinion refers to a concrete notion that implies a moral principle the essence of which makes possible the legal recognition of human rights. (Schultziner, 2007, pp. 73-92). Thus, this concept functions as a form of utilitarianism of the rules according to which individuals must conform to human dignity because it is the only principle according to which it is possible to maximize human well-being, in the sense established by the categorical imperative of Kantian origin which attests to the treatment of each individual in itself, and a second opinion outlines the difficulty of conceptualizing human dignity which is argued by the flexibility of the legal qualifications that define it.

In legal terms, human dignity simultaneously fulfils the quality of: (1) supreme normative value - being identified as a foundation and positivist legitimation of all human prerogatives; (2) legal principle - representing a fundamental idea that shapes, the legal norm through which a certain 
individual prerogative is enshrined; (3) human right - this legal consecration of dignity is enshrined through the fundamental laws of the states of the world.

Human dignity through the construction of legislation becomes a priority in the relationship between state and citizen. Thus, in Chapter I, with the marginal name Fundamental Rights, the Constitution of the Federal Republic of Germany states that: Human dignity is inviolable. Its observance and protection are in the attention of the state. Similarly, Article 10 of the Constitution of South Africa regulates the right of every individual to respect for and protection of buman dignity ${ }^{1}$. Constitutional jurisprudence demonstrates that the field of human dignity is convergent and evolves towards identifying the legal meaning of human dignity in a negative way; consequently, treating the individual in a way that creates deficiencies in the exercise of the right to dignity is equivalent to reifying him.

In this regard we mention the case of Prinsloo vs. Van der Linde (Constitutional Court Of South Africa, 1997), in which the Constitutional Court of South Africa responds by a judgment recognizing the dignity of persons of color (Constitutional Court Of South Africa, 1997).

In practice of the German Constitutional Court raises the issue of dignity through a case that calls into question the sentencing of an individual to life imprisonment, without the vocation to benefit from bail. Regarding this punitive possibility, the Constitutional Court of the Federal Republic of Germany held that: the state must consider every individual in society as having equal value (Köhne, 2003, p. 227).

In Romania, the Fundamental Law establishes at a high level a special attention on human dignity in the context of the constitutionalization of freedoms. By jurisprudence, the Romanian Constitutional Court has assigned a hybrid legal nature to the concept of human dignity, this being decomposed according to the following meanings: (Constitutional Court, 2019, paragraphs 47-53).

The Charter of Fundamental Rights of the European Union (European Union, 2012) individualises human dignity both structurally

\footnotetext{
1 Adopted on 8 May 1996 and amended by the Constitutional Assembly on 11 October 1996.
} 
(organized in 7 Titles, the Charter begins with the Title entitled "Dignity") and substantially.

Assimilated in the structure of the individual, dignity cannot be justified as a right of a singular nature, it is conceived around the natural person consecrated with other elements such as private life, social life, public order, inviolability, etc.

\section{Analytical coordinates of human dignity in crisis situations}

The lack of conceptual clarity related to human dignity is compressed by the feature of human dignity of being a synthetic tool, which summarizes the main issues of human rights. By eluding any form of standardization, human dignity refers to philosophical, religious, sociological elements, but also to the way in which human nature relates to and incorporates all these facets. Starting from the foundation of human dignity that of basic prerogative attributed to each individual on the basis of his humanity, - the literature has developed multiple attempts focused on capturing the essence of dignity. In this sense we mention Christopher McCrudden, who retains in the content of human dignity at least 3 elements: (1) the human being has a complex structure, only by the fact of its existence; (2) human dignity as an intrinsic value should be recognized and respected by all members of society; (3) the recognition of the intrinsic value of the individual requires that the state be perceived as an instrument placed at the disposal of the individual human being (we refer in this point to the claim of the limited state) (McCrudden, 2008, pp. 655-679).

Human dignity has cross-cutting value when it has implications for most human rights and freedoms; of the latter, the right to life is inextricably linked to human dignity because it ensures the ontological premise of human dignity, and human dignity describes the optimal legal conditions for the exercise of the right to life.

The reasoning that human dignity brings together in its sphere all human prerogatives, fulfilling their content, is based on the opinion that dignity is recognized, the prerogative, as the starting point of all human rights and, implicitly, on the characteristics of human rights established at the level of the international community by the United Nations. 
In this sense, universality, inalienability, interdependence and interrelationship, equality and non-discrimination, participation and inclusion, responsibility and legality ${ }^{2}$, build the idea of the pre-existence of a common value, applicable to all human rights and identifiable in the content of human dignity.

In times of crisis, the design of human dignity taking into account the two elements: (1) the constituent elements of fundamental freedoms and (2) the exercise of the right to life, generates some specific challenges.

On the one hand, we take into account the fact that the state authorities tend to put the issue of insurance in the background and the protection of human rights in extraordinary circumstances such as those related to the COVID-19 pandemic; on the other hand, there are some ethical issues regarding the guarantee and exercise of the right to life of individuals in the context of insufficient medical resources and the overcrowding of the health system (Bulgaru \& Berna, 2020, p. 10).

In the situation where we are faced with the subjection of individual rights and freedoms to limitations and restrictions in the conditions of the COVID-19 pandemic, it is necessary to question one aspect: whether the possibility of activating limitations and restrictions lies in the fact that human rights have no absolute character, what are the implications on the guarantee of human dignity - the latter, having a trans-normative character and necessarily deriving from the nature of the human being, will be subject to the same limitations and restrictions? Are there viable guarantees under which human dignity can be safeguarded in times of crisis? In response to the challenge, we can say that the association between dignity and the right to life of the analytical approach leads to the forefront of other legal sensibilities such as: the acquisition of the international community to include the right to life in the category of jus sangvinis norms. In conclusion, crisis management directly imposes fewer positive effects in the exercise of human dignity and implicitly in the exercise of the protection of life.

\footnotetext{
${ }^{2}$ https://www.unfpa.org/resources/human-rightsprinciples
} 


\section{Limitations on dignity and human rights in the COVID-19 pandemic}

At international level, Article 4 prescribes for both International Covenants the coordinates for activating the derogation and limitation of rights provided for in the two instruments.

In this respect, the possibility of derogation exists with regard to the rights and freedoms provided for in the International Covenant ${ }^{3}$ on Civil and Political Rights, being established expresis verbis. In this context, the main requirements that must be met cumulatively to activate the derogation are: the existence of an major public danger that threatens the life of the population; the public danger is presented by a law; derogating measures may not be contrary with other obligations established under international law and the measures must not constitute a discriminatory act.

In the General Comment no. 29 formulated in connection with the explanation of article 4 of the Covenant, the Human Rights Committee notes both issues in paragraphs 3 and 4 , which are reminiscent of regulations that arise in the event of emergencies, artmate, medical or other global emergencies.

From the perspective of the Pandemic, Romania accessed Article 4 of the Covenant, communicating that Romania's permanent mission to the

\footnotetext{
3 According to Article 4 of the International Covenant on Civil and Political Rights: 1. Where an exceptional public danger threatens the existence of the nation and is proclaimed by an official act, the States Parties to the present Covenant may, within the strict limits of the requirements of the situation, take measures derogating from the obligations provided for in this Covenant, provided that such measures are not incompatible with their other obligations under international law and that they do not result in discrimination based solely on race, colour, sex, language, religion, or social background. 2. The preceding provision does not authorize any derogation from the provisions of Articles 6, 7, 8 (paragraphs 1 and 2), 11, 15, 16 and 18.3. States Parties to the present Covenant exercising their right of derogation shall, through the Secretary-General of the United Nations, promptly notify the other States Parties of the provisions from which they have derogated, and of the reasons for such derogation. A new communication will be made, through the same intermediary, on the date on which they ended the derogations. According to Article 4 of the International Covenant on Economic, Social and Cultural Rights: States Parties to the present Covenant recognize that with respect to the exercise of rights ensured by the State in accordance with this Covenant, the State may make such rights subject only to such limitations, only to the extent compatible with the nature of these rights and exclusively in order to promote the general welfare of a democratic society.
} 
United Nations requests that a Verbal Note addressed in this way be considered a warning for the purpose of activating Article 4 (3) of the Covenant; (...) spect to which the Romanian Authorities will be obliged to transmit information on the aspects appeared in the given situation (United Nations, 1996). This Declaration validates the possibility of derogating from the provisions of the Covenant and the conditions under which they operate: Under the to this international document a number of states have activated Article 4 of the Convention, allowing in this sense the limitation of some rights under exception.

Furthermore, the Declaration also notes the form of respect for human dignity, stating that: states are obliged to provide application of treatments to all patients in the situation of the pandemic, without establishing any current of discrimination (United Nations, 2020).

At European level, Article 15 of the European Convention for the Protection of Human Rights and Fundamental Freedoms establishes a derogating clause from the initial prerogatives whose source of inspiration relates to the provisions of Article 4 of the International Covenant on Civil and Political Rights. According to article 15, par. (1) of the Convention: in the event of an emergency, human freedoms may be waived or even limited (Council of Europe, 1953).

We note that the measures taken during the derogations are limited, the interpretation of Art. 15 of the Convention attests that the granting of the derogation does not amount to a concession granted to the State in the sense that it is is accepted restriction of rights. (European Court of Human Rights, 2020 p. 5).

The derogation from the level of protection present by the European Convention is, for States parties, a possibility and not an obligation in this context, and the COVID-19 pandemic represents, within the meaning of Article 15, a real and specific threat to the right to health and life of the individual.

In the conditions of the COVID-19 pandemic, Romania notified the General Secretariat of the Council of Europe, by the Verbal Note sent on March 17, 2020, the derogation from the Convention, offering the 
guarantees of permanent notification on the action to be adopted during the pandemic.

The Universal Declaration of Human Rights in the preamble states that human dignity is inherent in the human being - a fact that ensures its absolute character. The questioning of human dignity under the conditions of the application of limitations, derogations or suspensions is possible only in the external dimension of dignity - related to its exercise in connection with the realization of fundamental rights and freedoms.

\section{Issues on the right to life and human dignity in a pandemic crisis}

In the General Comment no. 3628, the Human Rights Committee interprets the exercise of the right to life in close connection with human dignity, mentioning in paragraph 3 that: that, man is free in his activity enjoying the life lived with dignity. In the situation presented, dignity is a dimension of the exercise of the right to life, being a requirement in itself that ensures the construction of the right to life.

In the legal system of the Council of Europe established under the European Convention for the Protection of Human Rights and Fundamental Freedoms, the notion of dignity is not used in expresis until the adoption of Protocol no. 13 (United Nations, 2019). The European norm places the "innate dignity of all human beings" in relation to its opposite, namely the abolition of the death penalty.

An aspect of the COVID-19 pandemic, the main issue concerning the right to life and, implicitly, human dignity consists in the way of selecting patients in conditions where medical resources are limited.

Another aspect concerns the extent to which medical staff can select patients for treatment with SARS-CoV-2 virus infection, depending on age, given that elderly patients with other morbidities are, usually, placed in lower positions compared to young or middle-aged patients.

Also, a special aspect is given by the decisions taken by patients in critical situations based on personal autonomy, which have as finality the renunciation of treatment.

In that regard, is a legitimate question whether the decision to subsequently take sorting by the medical staff can justify respect for personal 
autonomy expressed in the form of refusal of medical treatment? (Bulgaru \& Berna, 2020, p. 20).

In agreement with paragraph 9 of General Comment no. 36, the manifestation of the COVID-19 pandemic imposes new obligations on States Participating to the main international and regional actions in the field of human rights in order to ensure the right to a dignified life in favour of individuals. In this respect, it has been established as an obligation on the State to take all reasonable positive measures in response to foreseeable threats to life and health due to the risk of infection with the SARS-CoV-2 virus (European Court of Human Rights, 2013). States are primarily tasked with planning the response to the COVID-19 pandemic so that people's lives can be saved.

The lack of medical resources to solve the health crisis during the COVID-19 pandemic cannot lead to the idea of justifying the violation of the premises of a dignified life, the possible refusals to accept medication to the detriment of the health crisis or the patient's personal autonomy of not accepting the imposed medical protocol does not justify the establishment of the right to life and human dignity in a legal context.

The right to health - as a central element whose protection is disputed in the event of the COVID-19 pandemic - is not mentioned expresis verbis in the European Convention, its content elements being incorporated either in the sphere of the right to life (regulated by Article 2 of the Convention) or in the sphere of the right to privacy (contained in Article 8 of the Convention).

As previously presented, the pressure exerted by the effects of the COVID-19 pandemic on health systems brings to the fore ethical elements established in connection with the guarantee of the right to life and dignity, but also the identification of an order of priority on the issue of hospitalization at ATI of people infected with the SARS-CoV-2 virus or the identification of a non-discriminatory protocol for granting first aid or treatment measures in their favour

Taking into account the absolute novelty of the medical reality specific to the COVID-19 pandemic, in the absence of clear legal constructions, we will take into account the jurisprudential model developed 
by the European Court, applying it by analogy with the case Arskaya vs. Ukraine. In the present case, the Court ruled that the violation of art. 2 of the Convention in the situation where the action of the local health authorities does not regulate in a sufficiently clear manner the norms according to which the patients were hospitalized in the Intensive Care Unit. The flexible and interpretative provisions applicable to informed consent of patients are, in the Court's view, tantamount to the absence of appropriate rules in this area.

Conjugated, the two legal limitations are likely, according to the Court, to lead to a violation of Art. 2 of the Convention, in the sense that the health authorities have not taken sufficient measures to establish a regulatory framework capable of ensuring adequate protection of life (European Court of Human Rights, 2013).

Another aspect with ethical-moral implications on guaranteeing the right to life is to establish clarity on the appropriate way to exercise consent in the event that the patient infected with SARS-CoV-2 virus is in isolation, in Intensive Care Unit, and is in inability to be directly consulted about the therapeutic actions to which he will be subjected.

If there is a desire of the patient not to be resuscitated in the event of a collapse of the cardio-respiratory system, this must be documented in advance and, if this is not feasible, the indication not to have resurrected the patient must be transparent, clearly from the instructions provided by family members or other relatives of the patient. In this context, decision-making acts cannot be adopted unilaterally by healthcare providers nor can they be applied in a discriminatory but must be determined by assessing the consent of the person concerned or his or her family members in the best the interest of the suffering person.

International and regional human rights authorities have issued a Joint Declaration on the obligation of governments to promote and protect information transfer during the COVID-19 pandemic (United Nations, 2020). The document aims to establish the approaches to states during the COVID-19 pandemic. 


\section{Conclusions}

Human dignity is a compound of individual rights and freedoms, but also an element limited to the content and exercise of each human prerogative.

Restriction or derogation - as restrictive measures in in human rights - may not prejudice human dignity in its substantial dimension of content; the only legal consequences observed on dignity are in the conditions evoked identical to those produced on the right or freedom particularly concerned, and they belong to the sphere of exercise of the prerogative.

The man is the pawn around which the rights are conceived precisely to ensure a solid guarantee in the society in which the authorities of the states not infrequently through their superior position were imposed in the form of abuse through unjustified limitations on human rights.

In the current health crisis, the right to dignity and the right to life merge with each other, and states are responsible for making positive commitments to direct and appropriate intervention to protect all social groups in the event of SARS-CoV-2 infection.

\section{References}

Bulgaru, A., \& Berna, M. B. (2020). Problematica respectării demnității umane în condiții de criză din perspectiva implicațiilor etico-juridice generate de pandemia de COVID-19 [The issue of respecting human dignity in crisis conditions from the perspective of ethical and legal implications generated by the pandemic covit-19]. Drepturile omului, 20, 9-28. https://revista.irdo.ro/pdf/2020/revista_2_2020/01_Bulgaru_Berna.pdf

Constitutional Court. (2019, July 18). Decision No 464 of 18 July 2019 on the legislative proposal to revise the Constitution of Romania [Pl-x 331/3.07.2019]. Official Gazette of Romania, Part I, No 646 of 5 August 2019. https://www.ccr.ro/wp-content/uploads/2021/03/Decision-No-4642019.pdf

Council of Europe. (1953, September, 3). The Convention in 1950. The European Convention on Human Rights. https://www.coe.int/en/web/humanrights-convention/the-convention-in-1950

European Court of Human Rights. (2013, December 5). Case of Arskaya vs. Ukraine, 45076/05. Judgment. Strasbourg. Council of Europe. https://hudoc.echr.coe.int/app/conversion/pdf/?library=ECHR\&id=001 -138590\&filename $=001-138590$. pdf\&TID $=$ thkbhnilzk 
European Court of Human Rights. (2020, August 31). European Court of Human Rights, Guide on Article 15 of the European Convention on Human Rights - Derogation in Time of Emergency. Council of Europe. https://www.refworld.org/docid/6048e29816.html

European Union. (2012, September 26). Charter of Fundamental Rights of the European Union. Official Journal of the European Union, OJC. https://eurlex.europa.eu/legalcontent/EN/TXT/PDF/?uri=CELEX:12012P/TXT\&from=SL

Habermas, J. (2010). The concept of human dignity and the realistic utopia of human rights. Metaphilosophy, 41(4), 464-480. https://doi.org/10.1111/j.1467-9973.2010.01648.x

Hathaway, O., Lim, P., \& Stevens, M. (2020). COVID-19 and International Law Series - Human Rights Law: Right to Life. Just Security. https://www.justsecurity.org/73426/covid-19-and-international-lawseries-human-rights-law-right-to-life/

Köhne, M. (2003). Verfassungsmäßigkeit der lebenslangen Freiheitsstrafe 25 Jahre nach BVerfGE 45, 187 ff [Constitutionality of life imprisonment 25 years according to BVerfGE 45, 187 ff.]. Juristische Rundschau, (1), 5-9. https://doi.org/10.1515/juru.2003.1.5

McCrudden, C. (2008). Human Dignity and Judicial Interpretation of Human Rights. European Journal of International Law, 19(4), 655-724. https://doi.org/10.1093/ejil/chn043

Schultziner, D. (2007). Human Dignity: Functions and Meanings. In J. Malpas \& N. Lickiss (Eds.), Perspectives on Human Dignity (pp. 9-18). Springer.

South Africa: Constitutional Court. (1997, April 18). Prinsloo v Van der Linde and Another (CCT4/96) [1997] ZACC 5; 1997 (6) BCLR 759; 1997 (3) SA 1012 (18 April 1997). Southern African Legal Information Institute. http://www.saflii.org/za/cases/ZACC/1997/5.html

UN Human Rights Committee (HRC). (2019, September 3). General comment no. 36, Article 6 (Right to Life), 3 September 2019, CCPR/C/GC/35. UN Human Rights Committee (HRC). https://www.refworld.org/docid/5e 5e75e04.html

United Nations. (1966, December 16). Assembly resolution 2200A (XXI) of 16 December 1966 entry into force 23 March 1976, in accordance with Article 49. International Covenant on Civil and Political Rights. https://www.ohchr.org/en/professionalinterest/pages/ccpr.aspx

United Nations. (2020, April 30). Statement on derogations from the Covenant in connection with the COVID-19 pandemic. International Covenant on Civil and Political Rights.

https://www.ohchr.org/Documents/HRBodies/CCPR/COVIDstatement EN.pdf 
Human Dignity and Its Premises in the Pandemic Crisis

Gabriela NEMȚOI

United Nations. (2020, March 19). COVID-19: Governments must promote and protect access to and free flow of information during pandemic - International experts. United Nations. Human Rights Office of the High Commissioner.

https://www.ohchr.org/EN/NewsEvents/Pages/DisplayNews.aspx?New $\underline{\mathrm{IID}=25729}$ 